\title{
Lack of Discriminating Signs and Symptoms in Clinical Diagnosis of Influenza of Patients Admitted to the Hospital
}

\author{
A. M. v. d. Hoeven, M. Scholing, P. C. Wever, R. Fijnheer, M. Hermans, P. M. Schneeberger
}

\begin{abstract}
Objectives: Rapid diagnosis of influenza in hospitalised patients is important to prevent the transmission of the infection in the hospital. This prospective observational cohort study was designed to determine the relationship between the clinical diagnosis of influenza made by the physician at admission and the presence of influenza virus in patients with respiratory tract infections.

Methods:This prospective observational cohort study was conducted in a large Dutch teaching hospital in a period of four weeks during the influenza season 2004/2005. All patients of 18 years and older, admitted with respiratory tract infections were included in the study. Clinical and laboratory parameters, chest radiograph (CR), blood and sputum cultures and nasopharyngeal swab for polymerase chain reaction (PCR) were obtained for each patient. In addition, the physicians opinion at admission whether this patient had influenza was recorded.

Results: A total of 78 patients were hospitalized with respiratory tract infections. In 41 (53\%) of them influenza virus was detected by PCR. Among the patients that were positive for influenza virus by PCR, a clinical diagnosis of influenza was made in 18 cases (44\%). Conversely, clinical diagnosis of influenza was made in 16 out of 37 patients in whom influenza virus was not detected by PCR. Neither C-reactive protein, leucocytes count nor an infiltrate on CR were helpful in determining the cause of the respiratory tract infection.

Conclusions: The present findings failed to demonstrate a significant relationship between the clinical diagnosis of influenza and PCR detection of the virus. Also, the virus was present at least twice more often than influenza was clinically diagnosed. As a consequence, the decision to take protective measures to control spread of the virus should not rely on the clinical diagnosis.
\end{abstract}

Infection 2007; 35: 65-68

DOI 10.1007/s15010-007-6112-1

\section{Introduction}

In winter 2004/2005 the most extensive influenza epidemic of the past five years occurred in the Netherlands. The usual background of 3 per 10,000 cases of an influenzalike illness was exceeded largely, namely 104 per 10,000 inhabitants. [1] Based on recordings of the Dutch Institute for Healthcare Research (NIVEL) this influenza epidemic caused more serious illness than in previous years and a corresponding level of high mortality. In the southern regions of the country, influenza activity was the highest and accompanied by a two-fold increase in all-cause mortality.

Influenza is characterized by systemic symptoms like fever, cough, artralgia, headache, chills, malaise, fatigue and myalgia. However, there are various diseases with similar clinical features. This makes the clinical diagnosis of influenza in patients presenting at the Emergency Room (ER) difficult. [2, 3] The combination of fever and cough may be indicative for the clinical diagnosis of influenza during a seasonal epidemic. [4-7] In general practice at the ER however, differentiating viral from bacterial infections is difficult.

Nevertheless rapid diagnosis of influenza is important for prevention of transmission of the virus and treatment with antiviral drugs.

Laboratory diagnosis of influenza with pharyngeal culture of the virus is considered the 'gold standard'. However, results from cell culture take 2 to 14 days, and rapid diagnostic kits for influenza lack sensitivity. Polymerase chain reaction (PCR) is a sensitive and specific test for influenza, with test results obtainable within 24-48 hours. [8]

This prospective study was designed to determine the relationship between the clinical diagnosis of influenza

\footnotetext{
A. M. v. d. Hoeven (corresponding author), M. Scholing, P. C. Wever, R. Fijnheer, $\mathbf{M}$. Hermans, P. M. Schneeberger Dept. Medical Microbioloy and Infection Control, Jeroen Bosch Ziekenhuis, Postbus 90153, 5200 ME's-Hertogenbosch, the Netherlands; e-mail:am180476@hotmail.com or p.schneeberger@jbz.nl
} 
made by the physician at admission and the presence of influenza virus in patients with respiratory tract infections. The results of this study may be of importance for the management of influenza pandemic.

\section{Material and Methods}

This prospective observational cohort study was conducted during the influenza season 2004/2005 over a period of four weeks (week 8 until week 11) in a large Dutch teaching hospital in the southern regions of the country, where influenza activity was the highest. The hospital serves a semi-rural region with one major city of 100,000 inhabitants $\left(1250 \mathrm{~km}^{2}\right)$ with an overall population of 350,000 inhabitants. All patients of 18 years and older, presenting at the ER with respiratory tract infection, were questioned and examined to assess clinically whether this was a case of influenza or not. Prospective definitions of respiratory tract infection and of influenza-like illness were made available to the physician, according to definitions used in literature. [2,15] Influenza-like illness was defined as fever (defined as a temperature $>38$ degrees) with at least two of the following: cough, sore throat, myalgia and headache. [2] Only patients admitted to the hospital were included in the study.

The physician at the ER recorded the findings of the medical history and physical examination as well as the severity of the illness and risk of mortality with the Pneumonia Severity Index (PSI). [9] This score consists of patient parameters like age, underlying disease, physical and laboratory parameters. For each patient routine investigation was done: Laboratory investigation (full blood count, renal and liver function, C-reactive protein (CRP) and arterial blood gas), chest radiograph (CR), blood and sputum cultures, as well as a pharyngeal swab for PCR influenza. Not routinely serology for Mycoplasma, Chlamydia and Legionella was performed, however only in cases with clinical suspicion for infection with an atypical organism. On admission, the physician was asked to clinically diagnose each patient either as an influenza case or a non influenza case. As soon as the test results of PCR influenza virus were available, the physician in charge of the ward was contacted in order to take protective measures and adjust treatment. Test results of the PCR were available within 48 hours.

Pharyngeal swabs for he detection of influenza virus were simultaneously tested by (1) a real-time PCR directed at highly conserved regions coding for the matrix protein of influenza viruses $\mathrm{A}$ and $\mathrm{B}$ and (2) multiplex real-time PCR directed at highly conserved regions coding for the matrix protein of influenza virus $\mathrm{A}$ and the hemaglutinin gene segment of influenza virus B, including routine internal controls. $[10,11]$ Other materials like blood and sputum cultures were processed in the daily routine of the microbiological laboratory.

Data were processed with SPSS. Differences between patients with PCR influenza virus positive and negative were analysed with analysis of variance (ANOVA). Cross tabs were used for testing the correlation between discrete variables, ANOVA for testing the correlation between the mean values of a continuous variable in the two different groups of patients. $P$ values $<0.05$ were considered significant.

\section{Results}

A total of 78 patients were included in the study period (Figure 1). In 41 (53\%) out of 78 patients influenza virus was detected by PCR. There were no discrepant results between both PCR tests. 29

\begin{tabular}{|c|c|c|c|}
\hline $\begin{array}{l}\text { Patient } \\
\text { characteristics }\end{array}$ & $\begin{array}{l}\text { PCR influenza } \\
\text { virus negative } \\
(\mathrm{N}=37)\end{array}$ & $\begin{array}{l}\text { PCR influenza } \\
\text { virus positive } \\
(\mathrm{N}=41)\end{array}$ & $\begin{array}{l}\text { Statistical } \\
\text { significance }\end{array}$ \\
\hline Age (years)* & $\begin{array}{l}65 \pm 17 \\
\text { range } 22-88\end{array}$ & $\begin{array}{l}72 \pm 16 \\
\text { range } 32-94\end{array}$ & Ns \\
\hline Female/ Male & $14 / 23$ & $18 / 23$ & Ns \\
\hline $\begin{array}{l}\text { Suspicion } \\
\text { of influenza }\end{array}$ & 16 & 18 & Ns \\
\hline $\begin{array}{l}\text { Suspicion } \\
\text { bacterial } \\
\text { infection }\end{array}$ & 14 & 12 & Ns \\
\hline Not scored ${ }^{\mathrm{a}}$ & 7 & 11 & Ns \\
\hline $\begin{array}{l}\text { Leucocytes } \\
\left(10^{9} / \mathrm{l}\right)^{*}\end{array}$ & $\begin{array}{l}11.0 \pm 4,9 \\
\text { range } 1-25\end{array}$ & $\begin{array}{l}11.0 \pm 10,6 \\
\text { range } 1-70\end{array}$ & Ns \\
\hline $\operatorname{CRP}(\mathrm{mg} / \mathrm{l})^{*}$ & $\begin{array}{l}116 \pm 127 \\
\text { range } 6-527\end{array}$ & $\begin{array}{l}96 \pm 96 \\
\text { range } 6-324\end{array}$ & Ns \\
\hline $\begin{array}{l}\text { Infiltrate } \\
\text { on CR }\end{array}$ & 13 & 10 & Ns \\
\hline Temperature* & $\begin{array}{l}37,7 \pm 1,3 \\
\text { range } \\
34,5-40,2\end{array}$ & $\begin{array}{l}37,8 \pm 0,8 \\
\text { range } \\
36,3-39,3\end{array}$ & Ns \\
\hline Comorbidity $^{\mathrm{b}}$ & 24 & 20 & Ns \\
\hline COPD & 8 & 24 & $p<0,001$ \\
\hline $\begin{array}{l}\text { Treatment with } \\
\text { antibiotics }\end{array}$ & 34 & 38 & Ns \\
\hline $\begin{array}{l}\text { Length } \\
\text { of hospital } \\
\text { stay (days)* }\end{array}$ & $\begin{array}{l}12 \pm 11 \\
\text { range } \\
2-40\end{array}$ & $\begin{array}{l}10 \pm 7 \\
\text { range } \\
1-40\end{array}$ & Ns \\
\hline $\begin{array}{l}\text { Number of } \\
\text { patients died }\end{array}$ & 4 & 4 & Ns \\
\hline \multicolumn{4}{|c|}{$\begin{array}{l}{ }^{*} \text { Mean value; }{ }^{\text {a }} \text { Not scored means the physician could not make } \\
\text { a clear statement based upon clinical signs whether this patient } \\
\text { had influenza or not; }{ }^{b} \text { comorbidity e.g. diabetes mellitus, cardio- } \\
\text { vascular disease, renal insufficiency; } \pm \text { standard deviation from } \\
\text { the mean; Ns: Non significant }\end{array}$} \\
\hline
\end{tabular}

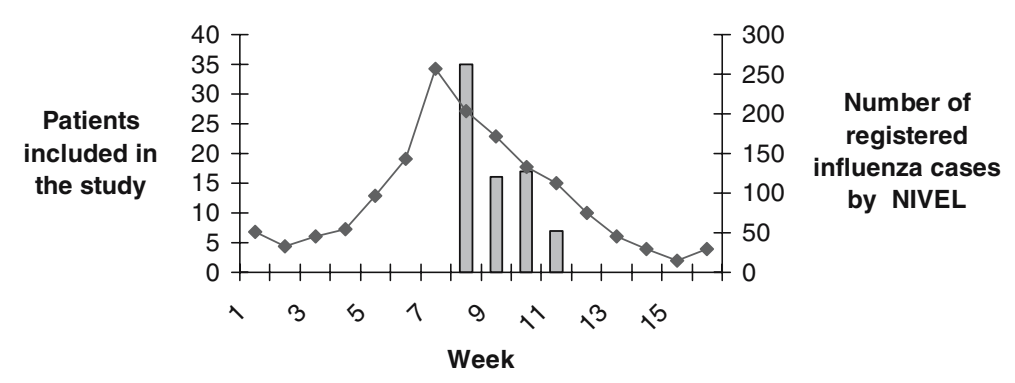

$\square$ Number of patients included in study Jeroen Bosch Ziekenhuis
- Number of patients with influenza/100,000, NIVEL Netherlands

Figure 1. Epidemiology of the 2005 Dutch influenza epidemic related to the patients included into the study. 


\begin{tabular}{|lll|}
\hline $\begin{array}{l}\text { Table } 2 \\
\text { Results bacteriological testing. }\end{array}$ & & \\
\hline Micro-organism & PCR negative & PCR positive \\
\hline Total & 37 & 41 \\
No diagnosis & 24 & - \\
Only influenza virus & - & 32 \\
H. influenzae & 6 & 5 \\
S. pneumoniae & 3 & 2 \\
Mycoplasma & 2 & 1 \\
Other & 2 & 1 \\
\hline
\end{tabular}

out of 41 patients tested positive for influenza A, 10 for influenza B and 2 for influenza A and B. The clinical diagnosis of influenza was made in 18 out of 41 cases in which influenza virus was detected by PCR. Conversely, clinical diagnosis of influenza was made in 16 out of 37 patients in whom influenza virus was not detected by PCR. Sensitivity and specificity of the clinical diagnosis were $60 \%$ and $53 \%$ respectively. Table 1 shows patient characteristics of the study cohort. Neither the value of CRP, leukocyte count nor the presence of an infiltrate on CR could discriminate wether this was a case of influenza or not. Mean body temperature at admission was similar in both groups and cough was present in $75 \%$ of all patients in both groups. More patients with chronic obstructive pulmonary disease (COPD) tested positive for influenza virus.

Table 2 shows results of bacteriological testing and serology. PSI score III or higher was significantly correlated with longer hospital stay, both for patients with PCR influenza virus negative $(\mathrm{p}=0.001)$ and for patients with PCR influenza virus positive $(\mathrm{p}=0.018)$ (Table 3$)$. Patients testing positive for PCR influenza virus had significantly higher PSI (score $>$ III) $(\mathrm{p}=0.014)$. PSI was significantly correlated with mortality. A total of 8 patients died, 4 in each group (Table 3). Patients with co morbidity like diabetes, cardiovascular disease and renal insufficiency had significantly longer duration of hospital stay $(p=0.03)$.

None of the patients included in the study had been isolated or treated with antiviral drugs.

\section{Discussion}

The results of this prospective cohort study show that 41 out of $78(53 \%)$ patients admitted with respiratory tract infection were PCR influenza virus positive. The high number of patients tested positive with PCR influenza virus can be explained by the fact that this influenza epidemic was more severe than in previous years and that its activity was highest in the southern regions of the country, where the study was conducted.

PCR is a reliable method for detection of the presence of influenza virus. However the presence of the influenza virus may not always be the cause of the illness leading to the hospital admission. We found no significant relationship between the clinical diagnosis of influenza and PCR detection of the virus. In our study clinical signs such as cough and fever were not helpful in discriminating the cause of respiratory infections in patients admitted to the hospital. Similar results have been observed in another study that shows only half of hospitalized patients with influenza actually meet the Center for Disease Control and Prevention (CDC) criteria for influenza. [15] These results are in contrast to other studies that show that a combination of clinical signs such as fever and cough have greater predictive value for influenza. [4-7, 13, 14] However, some of these studies were done retrospectively and most of them included mainly outpatients. [4-7] Performance of clinical diagnosis has also been assessed prospectively in a study on neuraminidase inhibitors. This study establishes a poor predictive value of the clinical case definition, precluding its use for decision-making in hospitals during influenza epidemics. [8] Patients presenting at our ER are usually treated by their family physician before they are referred to the ER. Also, most patients have comorbidity, like COPD, making a clinical sign like cough not helpful in discriminating the cause of the infection. Moreover, the hospital where the study is performed is a large training hospital, where the interns may be less experienced. However this is the case in many hospitals. Neither CRP, leukocytes count nor infiltrate on CR were helpful in determining the cause of the respiratory tract infection. This

\begin{tabular}{|c|c|c|c|c|}
\hline $\begin{array}{l}\text { Pneumoniae } \\
\text { Severity Index } \\
\text { risk class }\end{array}$ & $\begin{array}{l}\text { Mean duration of hospital stay } \\
\text { (days) for PCR influenza negative } \\
\text { patients }\end{array}$ & $\begin{array}{l}\text { Mean duration of hospital stay } \\
\text { (days) for PCR influenza positive } \\
\text { patients }\end{array}$ & $\begin{array}{l}\text { Number of patients } \\
\text { with PCR influenza } \\
\text { negative }\end{array}$ & $\begin{array}{l}\text { Number of patients } \\
\text { with influenza PCR } \\
\text { positive }\end{array}$ \\
\hline 1 & $6 \pm 4$ (range $2-14)$ & $6 \pm 5($ range $1-13)$ & 10 & 5 \\
\hline 2 & $8 \pm 2($ range $4-9)$ & $6 \pm 3($ range $2-9)$ & 9 & 5 \\
\hline 3 & $9 \pm 5($ range $4-15)$ & $10 \pm 3($ range $5-15)$ & 5 & 14 \\
\hline 4 & $17 \pm 11($ range $8-40)$ & $14 \pm 10($ range $5-40)$ & $9[3]^{\mathrm{a}}$ & $15[4]$ \\
\hline 5 & $32 \pm 7($ range $26-40)$ & $14 \pm 3($ range $11-16)$ & $4[1]$ & 2 \\
\hline
\end{tabular}


is in accordance with the fact that there was no correlation between clinical diagnosis made by the physician and the laboratory diagnosis of influenza. To be able to start this study directly at the beginning of the influenza epidemic, only a limited number parameters were studied due to logistic reasons. However, we think this reflects the actual practice during outbreaks in hospitals.

As was emphasized in the latest Dutch guidelines concerning 'Community Acquired Pneumonia' (CAP) [12], PSI is a useful tool for measuring the severity of the illness as well as predicting mortality. Results from this study show that PSI and the length of the hospital stay and mortality are significantly correlated. In this study population there was a significant correlation between PSI and outcome overall. However, PSI was not helpful in discriminating the cause of the infection.

Finally, the results of this study reveal the complexity of the management of patient care and infection control at ER's in case of influenza pandemic. Without implementation of tight guidelines epidemic situations may be hard to control. ER's will become overcrowded with sick people and physicians cannot predict which patient has influenza or not. We postulate that the decision to take protective measure like isolation and treatment with antiviral drugs should not rely on the clinical diagnosis. In case of influenza pandemic measures should be universally implemented to protect both patients and healthcare workers in hospitals. When diagnosis of influenza is confirmed patients should be treated with antiviral therapy and isolation measures should be taken. Antibacterial therapy can be avoided when there is no alternative diagnosis and all cultures and serology are negative. Also, depending on the severity of the illness using the PSI. In case of severly ill patients, PSI 3 or higher, treatment with both antiviral as well as antibacterial therapy should be considered.

\section{Contributors}

AMvdH conceived the study, collected data, performed the analysis and wrote the manuscript. MS conceived the study, collected data and revised the manuscript. PCW extensively revised the manuscript. RF conceived the study. $\mathrm{MH}$ revised the manuscript and was responsible for all molecular data. PMS conceived the study and extensively revised the manuscript. AMvdH and PMS are guarantors.

\section{Ethical approval}

The study was evaluated and approved by the medical ethical committee (METOPP) since only standard procedures were conducted in this study.

\section{References}

1. de Jong JC, Rimmelzwaan GF, Bartelds AIM, Meijer A, Fouchier RAM, Osterhaus ADME. Het influenzaseizoen 2004/'05 in Nederland met de grootste epidemie van de laatste 5 jaar, door virusvariant A/California, en de vaccinsamenstelling voor het seizoen 2005/'06. Ned Tijdschr Geneeskd 2005; 49: 2355-2561.

2. Peltola V, Reunanen T, Ziegler T, Silvennoinen $\mathrm{H}$, Heikkinen $\mathrm{T}$. Accuracy of clinical diagnosis of influenza in outpatient children. Clin Inf Diseases 2005; 41: 1198-2000.

3. van der Meer V, Knuisting Neven A, van den Broek PJ, Assendelft WJJ. Diagnostic value of $C$ reactive protein in infections of the lower respiratory tract: systematic review. BMJ 2005; 331: 26.

4. Call SA, Vollenweider MA, Horning CA, Simel DL, Mc Kinney WP. Does this patient have influenza? JAMA 2005; 293: 987-979.

5. Zambon M, Hays J, Webster A, Newman R, Keene O. Diagnosis of influenza in the community: relationship of clinical diagnosis to confirmed virological, serologic, or molecular detection of influenza. Arch Int Med 2001; 161: 2116-2122.

6. Boivin G, Hardy I, Tellier G, Maziade J. Predicting influenza infections during epidemics with use of a clinical case definition. Clin Infect Dis 2000; 31: 1166-1169.

7. Monto AS, Gravenstein S, Elliott M, Colopy M, Schweinle J. Clinical signs and symptoms predicting influenza infection. Arch Int Med 2000; 160: 3243-3247.

8. Ruest A, Michaud S, Deslandes S, Horst E. Comparison of the Directigen Flu A + B Test, the QuickVue Influenza test, and clinical case definition to viral culture and reverse transcription PCR for rapid diagnosis of Influenza virus infection. J Clin Microbiol 2003; 41: 3487-3493.

9. Fine MJ, Auble TE, Yealy DM, Hanusa BH, Weissfeld LA, Singer DE, Coley CM, Marrie TJ, Kapoor WN. A prediction rule to identify low-risk patients with community acquired pneumonia. N Engl J Med 1997; 336: 243-250.

10. van Elden LJ, Nijhuis $M$, Schipper P, Schuurman R, van Loon AM. Simultaneous detection of influenza viruses $A$ and $B$ using realtime quantitative PCR. J Clin Microbiol 2001; 39: 196-200.

11. Ward CL, Dempsey MH, Ring CJ, Kempson RE, Zhang L, Gor D, Snowden BW, Tisdale M. Design and performance testing of quantitative real time $P C R$ assays for influenza $A$ and $B$ viral load measurement. J Clin Virol 2004; 29: 179-188.

12. Schouten JA, Prins JM, Bonten $M$, Degener JE, Janknegt $R$, Hollander JMR, Jonkers R, Wijnands W, Verheij T, Sachs A, Kullberg BJ. Optimaliseren van het antibioticabeleid in Nederland. VIII. Herziene SWAB-richtlijnen voor antimicrobiële therapie bij thuis opgelopen pneumonie. Ned Tijdschr Geneesk 2005; 149: 2495-2500.

13. Walsh EE, Cox C, Falsey AR. Clinical features of influenza A infection in older hospitalized persons. J Am Geriatr Soc 50: 2002; 1498-1503.

14. Govaert TM, Dinant GJ, Aretz K, Knottnerus JA. The predictive value of influenza symptomatology in elderly people. Fam Pract 1998; 15: 16-22.

15. Babcock HM, Merz LR, Fraser VJ. Is influenza an influenza-like illness? Clinical presentation of influenza in hospitalized patients. Infect Control Hosp Epidemiol 2006; 27: 266-270. 